\section{Taxonomic} Note

\author{
Correspondence \\ B. J. Tindall \\ bti@dsmz.de
}

\title{
Challenging Opinion 75
}

\author{
B. J. Tindall
}

DSMZ - Deutsche Sammlung von Mikroorganismen und Zellkulturen GmbH, Inhoffenstrasse 7B, 38124 Braunschweig, Germany

\begin{abstract}
Opinion 75 issued by the Judicial Commission is based on an interpretation of the Rules of the International Code of Nomenclature of Bacteria (the Code) that failed to take into consideration changes made to the Code by the Judicial Commission prior to consideration of the original Request for an Opinion. Furthermore, closer examination of the Request indicates a number of contradictions that have been carried over into the published Opinion. The Judicial Commission is therefore requested to re-examine Opinion 75.
\end{abstract}

Opinion 75 issued by the Judicial Commission (2008), dealing with the names Methanothrix Huser et al. 1983, Methanothrix soehngenii Huser et al. 1983, Methanothrix thermophila Kamagata et al. 1992 and Methanosaeta thermophila, was the subject of discussions at both the Paris (2002) (De Vos et al., 2005) and San Francisco (2005) (Tindall et al., 2008) meetings of the Judicial Commission. Possible problems with the interpretation of the International Code of Nomenclature of Bacteria (the Code) were discussed at the meeting in San Francisco and it was agreed that the Opinion should be published as originally discussed and formulated, and that possible problems with the Opinion should be documented. A key issue remains the fact that Opinion 75 has used the wording of Rule 31a that was printed in the 1990 revision of the Code (Lapage et al., 1992), whereas that wording was changed, with retroactive consequences, at the 1999 meetings of the Judicial Commission in Sydney, and the change came into effect with the publication of the minutes of the meetings of the Judicial Commission and the International Committee on Systematics of Prokaryotes (ICSP) (De Vos \& Trüper, 2000; Labeda, 2000).

As printed in the 1990 revision of the Code (Lapage et al., 1992), Rule 31a reads:

'The name of a species or subspecies is not validly published if the description is based upon studies of a mixed culture of more than one species or subspecies. This does not apply to descriptions based chiefly on morphology (e.g., Achromatium oxaliferum Schewiakoff 1893)'.

As published in the minutes of the 1999 meetings of the Judicial Commission (De Vos \& Trüper, 2000), the Rule reads:

'The name of a species or a subspecies is not validly published if the description is demonstrably ambiguous and cannot be critically identified for purposes of the precise application of the name of a taxon. Examples: 'Methanobacillus omelianskii', whose description included all component species, was treated as a single species and was thus illegitimate. Syntrophobacter wolinii Boone and Bryant 1984 is legitimate, because the species description applies to one member of the syntrophic association with a hydrogen-producing organism'.

The reason for changing the wording of Rule 31a centres on the fact that the old wording would make the names of syntrophic organisms (usually two-component systems, both components being 'known') 'not validly published'. For example, the type of Heliothrix oregonensis is also not a pure culture, and is a co-culture with a strain of Isosphaera pallida (Pierson et al., 1985).

The new wording means it is now important to consider whether 'the description is demonstrably ambiguous and cannot be critically identified for purposes of the precise application of the name of a taxon'. In studies on the type strains of the species Methanothrix soehngenii and Methanothrix thermoacetophila, Touzel et al. (1988), Patel \& Sprott (1990), Stackebrandt et al. (1982) and Kamagata et al. (1992) used either one or both of the type strains in their studies of protein patterns, DNA-DNA hybridization, $\mathrm{G}+\mathrm{C}$ content and 16S rRNA gene sequencing, without addressing the question of whether the filament-forming methanogen described by the original authors could be 'critically identified'; in other words, they accepted the fact that they were dealing with data obtained from the methanogen. Patel \& Sprott (1990), however, called into question the purity of strain Opfikon (the type of Methanothrix soehngenii) in order to create the new genus Methanosaeta, with Methanosaeta concilii as the type species. They also proposed that Methanothrix thermoacetophila (originally based on a type strain that was not axenic; Nozhevnikova \& Chudina, 1984) should be transferred to the genus Methanosaeta. These authors proposed to revive the name as Methanosaeta thermoacetophila, although this is an action reserved for names in use prior to 1 January 1980 and not included on the 
Approved Lists of Bacterial Names (Skerman et al., 1980, 1989). However, the proposal is not accompanied by a formal description, although one is alluded to in the text, but a type strain is designated.

In contrast, Kamagata et al. (1992) considered that Methanothrix thermoacetophila is not validly published and created the name Methanothrix thermophila in the knowledge that the type strain of that species is a member of the same genogroup as Methanothrix thermoacetophila = Methanosaeta thermoacetophila . Furthermore, Kamagata et al. (1992) 'reject' the name Methanothrix ('Methanosaeta') thermoacetophila. However, 'only the Judicial Commission can place names on the list of rejected names (nomina rejicienda)' (see Rule 23a, Note 4, and Appendix 4, Rule 56a). The authors also do not appear to have been aware that the name Methanosaeta thermoacetophila Patel and Sprott 1990 is typified by an axenic culture (Patel \& Sprott, 1990).

It is important to document the following facts. Based on published data:

(i) the type strains of Methanothrix soehngenii (Opfikon) and Methanothrix concilii $=$ Methanosaeta concilii (strain GP6) are known to be members of the same species;

(ii) the type strains of Methanothrix thermoacetophila $=$ Methanosaeta thermoacetophila (Z-517) and Methanothrix thermophila (strain $\mathrm{P}_{\mathrm{T}}$ ) are known to be members of the same genogroup, and the wording of Kamagata et al. (1992) is such that this may be interpreted to mean the same species.

One problem centres around the use of type strains that are known not to be axenic cultures (but this also applies to syntrophic organisms). The current wording of Rule 31a does not forbid such cultures, and has replaced the old wording. All Requests for an Opinion and interpretations of the taxonomy of the species in the genera Methanothrix and Methanosaeta (Boone, 1991; Boone \& Kamagata, 1998) are based on the old wording. Based on the current wording, it would be possible to accept strains Opfikon and Z-517 as type strains of a species. In both cases, there is documented scientific evidence that the filament-forming methanogens present can be clearly identified in these cultures and that they may be compared with other, axenic, strains without problems arising. However, the ICSP should also actively discourage the use of 'undefined' mixed cultures of 'natural populations' as types. The question of syntrophs/symbiotic associations certainly needs to be tackled, and modern methods seem to allow us to clearly separate 'A' from ' $B$ '.

Wayne (1994) stated that adopting strain GP6 (the type strain of Methanothrix concilii) as the neotype of Methanothrix soehngenii 'would have the effect of reducing the name Methanothrix concilii to a synonym and rendering it invalid'. However, this is not the case, since data presented already indicate that the two species names should be treated as synonyms, and such names do not become invalid.
Boone \& Kamagata (1998) in their original Request for an Opinion indicated that, since the type strain of Methanothrix soehngenii Huser et al. 1983 is not a pure culture, the name would be illegitimate, a conclusion that contradicts the revised wording of Rule 31a. Furthermore, these authors also concluded that the name Methanothrix thermoacetophila was never validly published, although the name appears on Validation List 25 (Nozhevnikova \& Chudina, 1988) and on Validation List 31 (Nozhevnikova \& Chudina, 1989). This organism was also not represented by a pure culture at the time that the name was first included on a Validation List. This strain has since been brought into axenic culture in the DSMZ (H. Hippe, personal communication).

In formulating its Opinion, the Judicial Commission had not been asked to rule on the question of whether the names Methanothrix thermoacetophila and Methanosaeta thermoacetophila were validly published, nor did they vote on this aspect. The interpretation of Boone \& Kamagata (1998) may not be correct, and the status of these names has a direct bearing on their request.

The original description of Methanothrix concilii (Patel, 1984) included a G + C determination that was one of the reasons for suggesting that this organism represented a novel species. The original values have since been shown to be incorrect. As long as Methanothrix soehngenii and Methanothrix concilii were treated as different species, Patel (1984) did not call into question the published data collected on Methanothrix soehngenii. It should also be noted that, although Touzel et al. (1988) indicated that Methanothrix soehngenii and Methanothrix concilii should be treated as synonyms, their proposal that the name Methanothrix concilii be rejected has no standing in nomenclature.

Kamagata et al. (1992) have also indicated that the name Methanothrix thermoacetophila should be rejected because the type was originally not based on a pure culture. However, they are not entitled to make this ruling, and the only question would be whether the name was validly published. The type strain of Methanothrix thermoacetophila is also a member of the same species as the type strain of Methanothrix thermophila.

The following points are critical to a re-evaluation of the arguments.

(i) Opinion 75 has incorrectly indicated that the name Methanothrix soehngenii should be rejected, when the issue under discussion should have been whether the name was validly published. It is unclear whether the Judicial Commission can reject a name that has no standing in nomenclature.

(ii) The changes to Rule 31a are retroactive and would have a significant effect on the way that the names of a number of syntrophs, as well as Heliothrix oregonensis, are treated. The issue of whether characteristic properties such as morphology and methane production are sufficient for one 
to consider the name as validly published, despite the presence of other organisms, can be evaluated from a different perspective under the new wording.

(iii) The new wording is retroactive and has an effect on the status of names such as Methanothrix soehngenii. The question of the purity of the type strain plays less of a role, provided that it is possible to attribute the properties of the culture to a defined partner, making it possible to consider such names as validly published.

(iv) The arguments of Patel \& Sprott (1990) centre on the purity of the type strain of Methanothrix soehngenii, a consequence of changes to the wording of Rule 31a being that the interpretation that the name Methanothrix soehngenii is not validly published may not be correct. As such, the creation of the genus name Methanosaeta and the species name Methanosaeta concilii would be in conflict with the Code, since the genus name Methanothrix and Methanothrix concilii may be considered to be validly published.

(v) The name Methanothrix thermoacetophila may also be validly published, and its type strain is a member of the same species as the type strain of Methanothrix thermophila.

(vi) The issue of whether the name Methanothrix thermoacetophila is validly published has a direct bearing on the status of the name Methanosaeta thermoacetophila, which, in turn, influences the status of the names Methanothrix thermophila and Methanosaeta thermophila.

(vii) The genus name Methanothrix appears on Validation List 10 (Huser et al., 1983), as does the species name Methanothrix soehngenii. The species name Methanothrix concilii appears on Validation List 17 (Patel, 1985). The genus name Methanosaeta and the species names Methanosaeta concilii and Methanosaeta thermoacetophila appear in an original publication in the IJSB (Patel \& Sprott, 1990). The species name Methanothrix thermoacetophila appears on Validation Lists 25 and 31 (Nozhevnikova \& Chudina, 1988, 1989). Kamagata et al. (1992) use the name Methanothrix ('Methanosaeta') thermophila, but formally propose the name Methanothrix thermophila in an original article in the IJSB. The name Methanosaeta thermophila is proposed in conjunction with a Request for an Opinion (Boone \& Kamagata, 1998).

\section{Acknowledgements}

I would like to thank Dr H. H. Hippe, formerly of the DSMZ, and Dr J. P. Euzéby for valuable help in evaluating the problems associated with the nomenclature of these organisms.

\section{References}

Boone, D. R. (1991). Strain GP6 is proposed as the neotype strain of Methanothrix soehngenii ${ }^{\mathrm{VP}}$ pro synon. Methanothrix concilii ${ }^{\mathrm{VP}}$ and Methanosaeta concilii ${ }^{\mathrm{VP}}$. Request for an Opinion. Int J Syst Bacteriol 41, 588-589.

Boone, D. R. \& Kamagata, Y. (1998). Rejection of the species Methanothrix soehngenii ${ }^{\mathrm{VP}}$ and the genus Methanothrix ${ }^{\mathrm{VP}}$ as nomina confusa, and transfer of Methanothrix thermophila ${ }^{\mathrm{VP}}$ to the genus Methanosaeta $^{\mathrm{VP}}$ as Methanosaeta thermophila comb. nov. Request for an Opinion. Int J Syst Bacteriol 48, 1079-1080.

De Vos, P. \& Trüper, H. G. (2000). Judicial Commission of the International Committee on Systematic Bacteriology. IXth International (IUMS) Congress of Bacteriology and Applied Microbiology. Minutes of the meetings, 14, 15 and 18 August 1999, Sydney, Australia. Int J Syst Evol Microbiol 50, 2239-2244.

De Vos, P., Trüper, H. G. \& Tindall, B. J. (2005). Judicial Commission of the International Committee on Systematics of Prokaryotes. Xth International (IUMS) Congress of Bacteriology and Applied Microbiology. Minutes of the meetings, 28, 29 and 31 July and 1 August 2002, Paris, France. Int J Syst Evol Microbiol 55, 525-532.

Huser, B. A., Wuhrmann, K. \& Zehnder, A. J. B. (1982). Methanothrix soehngenii gen. nov. sp. nov., a new acetotrophic non-hydrogenoxidizing methane bacterium. Arch Microbiol 132, 1-9.

Huser, B. A., Wuhrmann, K. \& Zehnder, A. J. B. (1983). Methanothrix soehngenii gen. nov., sp. nov. In Validation of the Publication of New Names and New Combinations Previously Effectively Published Outside the IJSB, List no. 10. Int J Syst Bacteriol 33, 438-440.

Judicial Commission (2008). Rejection of the genus name Methanothrix with the species Methanothrix soehngenii Huser et al. 1983 and transfer of Methanothrix thermophila Kamagata et al. 1992 to the genus Methanosaeta as Methanosaeta thermophila comb. nov. Opinion 75. Int J Syst Evol Microbiol 58, 1753-1754.

Kamagata, Y., Kawasaki, H., Oyaizu, H., Nakamura, K., Mikami, E., Endo, G., Koga, Y. \& Yamasato, K. (1992). Characterization of three thermophilic strains of Methanothrix ("Methanosaeta") thermophila sp. nov. and rejection of Methanothrix ("Methanosaeta") thermoacetophila. Int J Syst Bacteriol 42, 463-468.

Labeda, D. P. (2000). International Committee on Systematic Bacteriology. IXth International (IUMS) Congress of Bacteriology and Applied Microbiology. Minutes of the meetings, 14 and 17 August 1999, Sydney, Australia. Int J Syst Evol Microbiol 50, 2245-2247.

Lapage, S. P., Sneath, P. H. A., Lessel, E. F., Skerman, V. B. D., Seeliger, H. P. R. \& Clark, W. A. (editors) (1992). International Code of Nomenclature of Bacteria (1990 Revision). Bacteriological Code. Washington, DC: American Society for Microbiology.

Nozhevnikova, A. N. \& Chudina, V. I. (1984). The morphology of the thermophilic acetate methanogenic bacterium Methanothrix thermoacetophila n. sp. Microbiology (English translation of Mikrobiologiia) 53, 618-624.

Nozhevnikova, A. N. \& Chudina, V. I. (1988). Methanothrix thermoacetophila sp. nov. In Validation of the Publication of New Names and New Combinations Previously Effectively Published Outside the IJSB, List no. 25. Int J Syst Bacteriol 38, 220-222.

Nozhevnikova, A. N. \& Chudina, V. I. (1989). Methanothrix thermoacetophila sp. nov. In Validation of the Publication of New Names and New Combinations Previously Effectively Published Outside the IJSB, List no. 31. Int J Syst Bacteriol 39, 495-497.

Patel, G. B. (1984). Characterization and nutritional properties of Methanothrix concilii sp. nov., a mesophilic, aceticlastic methanogen. Can J Microbiol 30, 1383-1396.

Patel, G. B. (1985). Methanothrix concilii sp. nov. In Validation of the Publication of New Names and New Combinations Previously Effectively Published Outside the IJSB, List no. 17. Int J Syst Bacteriol 35, 223-225.

Patel, G. B. \& Sprott, G. D. (1990). Methanosaeta concilii gen. nov., sp. nov. ("Methanothrix concilii") and Methanosaeta thermoacetophila nom. rev., comb. nov. Int J Syst Bacteriol 40, 79-82. 
Pierson, B. K., Giovannoni, S. J., Stahl, D. A. \& Castenholz, R. W. (1985). Heliothrix oregonensis, gen. nov., sp. nov., a phototrophic filamentous gliding bacterium containing bacteriochlorophyll $a$. Arch Microbiol 142, 164-167.

Skerman, V. B. D., McGowan, V. \& Sneath, P. H. A. (editors) (1980). Approved lists of bacterial names. Int J Syst Bacteriol 30, 225-420.

Skerman, V. B. D., McGowan, V. \& Sneath, P. H. A. (editors) (1989). Approved Lists of Bacterial Names (Amended Edition). Washington, DC: American Society for Microbiology.

Stackebrandt, E., Seewaldt, E., Ludwig, W., Schleifer, K. H. \& Huser, B. A. (1982). The phylogenetic position of Methanothrix soehngenii, elucidated by a modified technique of sequencing oligonucleotides from 16S rRNA. Zentralbl Bakteriol Mikrobiol Hyg I Abt C 3, 90-100.
Tindall, B. J., De Vos, P. \& Trüper, H. G. (2008). Judicial Commission of the International Committee on Systematics of Prokaryotes. XIth International (IUMS) Congress of Bacteriology and Applied Microbiology. Minutes of the meetings, 23, 24 and 27 July 2005, San Francisco, CA, USA. Int J Syst Evol Microbiol 58, 1737-1745.

Touzel, J. P., Prensier, G., Roustan, J. L., Thomas, I., Dubourguier, H. C. \& Albagnac, G. (1988). Description of a new strain of Methanothrix soehngenii and rejection of Methanothrix concilii as a synonym of Methanothrix soehngenii. Int J Syst Bacteriol 38, 30-36.

Wayne, L. G. (1994). Actions of the Judicial Commission of the International Committee of Systematic Bacteriology on Requests for Opinions published between January 1985 and July 1993. Int J Syst Bacteriol 44, 177-178. 